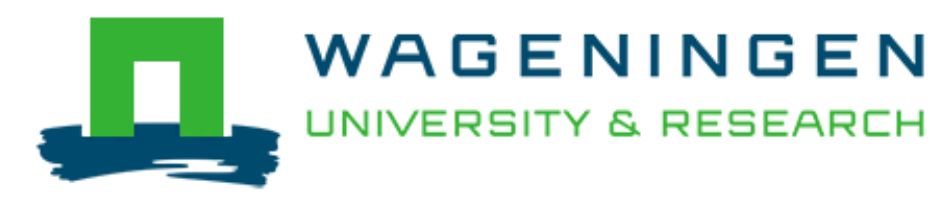

\title{
Food from the ocean; towards a research agenda for sustainable use of our oceans' natural resources
}

Van Hoof, L., Fabi, G., Johansen, V., Steenbergen, J., Irigoien, X., Smith, S., ... Kraus, G.

This is a "Post-Print" accepted manuscript, which has been published in "Marine Policy"

This version is distributed under a non-commercial no derivatives Creative Commons (c) (1) (2) $\Theta$ reproduction in any medium, provided the original work is properly cited and not used for commercial purposes. Further, the restriction applies that if you remix, transform, or build upon the material, you may not distribute the modified material.

Please cite this publication as follows:

Van Hoof, L., Fabi, G., Johansen, V., Steenbergen, J., Irigoien, X., Smith, S., ... Kraus, G. (2019). Food from the ocean; towards a research agenda for sustainable use of our oceans' natural resources. Marine Policy, 105, 44-51.

https://doi.org/10.1016/j.marpol.2019.02.046 


\section{Food from our Oceans; towards a research agenda for sustainable use of our oceans' natural} resources.

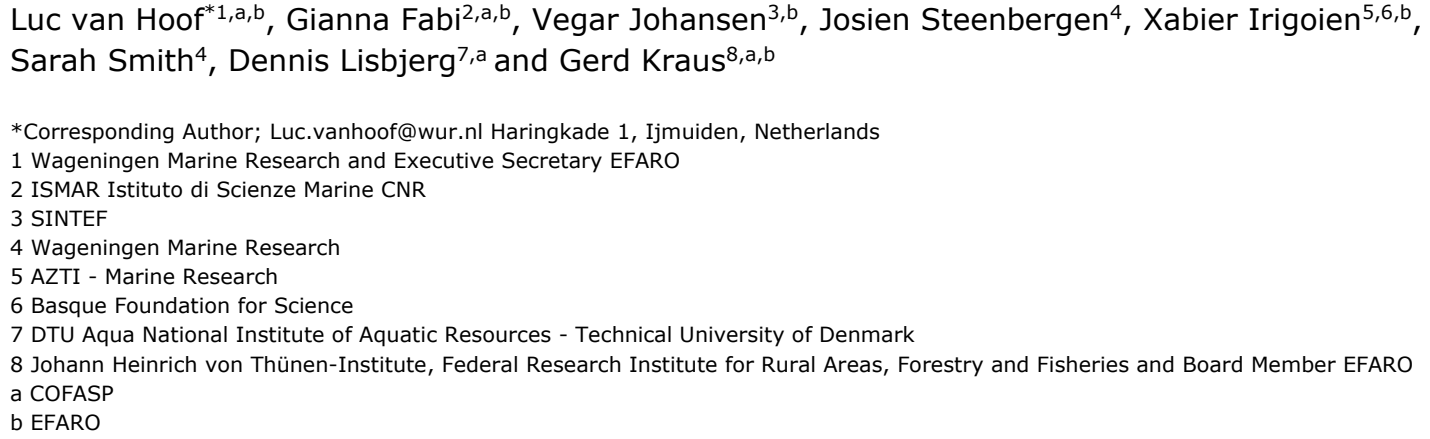

\section{Abstract}

By 2050 it is expected that food, clean drinking water and sustainable energy has to be produced for a world population of close to 10 billion people. Our seas and oceans represent $71 \%$ of earth's surface, yet its space and resources today are not sustainably utilised to their full extent. The importance of the use of the marine environment is within the EU widely acknowledged and reflected in such agendas as the EU Blue Growth strategy, the Food 2030 agenda and the Food from our Oceans vision. In order to substantiate the vision to increasingly feed the world population from our oceans, a foresight exercise was implemented to construct an agenda of the science needed in the realm of fisheries, aquaculture and seafood. This resulted in a research agenda that is logically argued and based on an analysis made by stakeholders and experts which led to the identification of priorities having a scientific analytical basis as well as a societal reference. The process and the results of this foresight exercise are presented and are put in the wider context of Europe's research agenda towards 2050. In order to bring about the required Blue Revolution, substantial effort should be rendered to the science and innovation needed to support this development.

Key words: Food from our oceans, fisheries, aquaculture, seafood processing, research

\section{Introduction}

A growing human population, 9.7 billion by 2050 according to United Nations estimates [1, 2], and the expectations of citizens from an increasingly prosperous developing world will intensify the global demand for food [3]. Not only will there be many more people, but today's nutritional challenges (hunger, undernutrition and micronutrient deficiencies), coupled with the expectations of citizens in an increasingly prosperous world, where people are eating more meat and fish in their diets, will intensify the global demand for food and biomass. Given current trends, total food demand is projected to increase by $60 \%$ by 2050 , according to the Food and Agriculture Organisation of the UN [2]. This will push conversion of land to crops and pasture as well as putting pressure on freshwater reserves that are already in many cases over-exploited and threatened by global warming [3]. Any additional biomass demand other than for food, such as for bioenergy or feed, adds further pressure and their expanded use should be carefully investigated [4].

In this paper these global challenges will be addressed within a European context. According to the EU Blue Growth strategy (2012) further clearing of forests or draining of wetland or depletion of marine resources and ecosystems will deprive future generations of the benefits they provide. Therefore, there is a need to look how the ocean, which represents $71 \%$ of the planet, can deliver human necessities such as food and energy in a way that is more sustainable [5]. Following the EU Food 2030 strategy (2016) this should include (next to developments in the sustainable use of land and soil) the sustainable use of marine waters and biodiversity as providers of ecosystem services upon which food production relies [9].

In Europe currently this consideration on how to sustainably harvest more food from the oceans $[2,6]$ is reflected in such initiatives as the 2012 EU Blue Growth strategy [5, 7], the 2014 EU communication on innovation in the blue economy [8], the 2016 EU FOOD 2030 initiative [9] the 2016 EU Ocean Governance initiative [10] and the initiative of the EU College of Commissioners, led by Commissioner Vella, to request 
scientific advice in the area of food and biomass from the oceans [11]. Hence there is the necessity and the political will to investigate "How can more food and biomass be obtained from the oceans in a way that does not deprive future generations of their benefits" [3]. Next to this political will there is of course also the necessity to develop the science underpinning and enabling this development. The COFASP ERAnet ${ }^{1}$, $\mathrm{created}$ to address actions envisaged within fisheries, aquaculture and seafood, undertook under the auspices of EFARO (the organisation of the European Fisheries and Aquaculture Research Organisations) a foresight study to develop such a strategic research agenda in the European context for fisheries, aquaculture and seafood processing.

This foresight exercise is embedded in an array of initiatives, in the area of the use of the oceans and in particular fisheries and (marine) aquaculture, focussed on identifying research needs. For example the European Standing Committee on Agricultural Research (SCAR) has implemented a scenario study on Sustainable Agriculture, Forestry and Fisheries in the Bio-economy [13]. SCAR's working group SCARFish has presented an overview of fisheries and aquaculture research currently being undertaken and, based on a gap analysis, has produced suggestions for future research [14]. JPI Oceans developed a Strategic Research and Innovation Agenda 2015-2020 [15]. Other Strategic Research and Innovation Agendas in this field were developed by BLUEMED [16] and BONUS [17]. Regularly topical studies in the marine and maritime field are being presented by for example organisations such as EFARO. The European Marine Board provides regular pan-European summaries of the current status of marine research, priority recommendations and future scientific challenges in the context of European societal needs in their Navigating the Future series [18, 19]. Together with the Marine Biotechnology ERA-NET the European Marine Board developed a policy brief on Marine Biotechnology [20].

Today a main challenge lies in how to develop the current way of use of the natural resources of our oceans against a backdrop of the global challenges such as accommodating the need for food, sustainable energy and fresh water. In addition, adaptation to climate change and mitigation of its negative consequences rate equally high among societies' grand challenges. At the same time technological progress is advancing at tremendous rates; making use of novel technology is a must to turn these grand challenges into opportunities. Under these circumstances, characterized by uncertainty, innovation and change, the use of scenario planning techniques is a useful tool to cope with uncertainty and complexity $[28,29]$. The scenario construction process is one of inclusiveness and accommodation of all perspectives $[21,22]$, and the complexity of the problems and the need to address them collectively require methods that are as rigorous and participatory as possible so that the individuals involved may identify the appropriate problems and agree upon solutions [23].

Scenarios as mental models are extremely useful in strategic foresight processes since they allow to structure complex systems and create tangible images of potential futures and their relationship to the present world [32]. There are many different forms of scenario studies and many different techniques that can be applied such as trend analysis and trend extrapolation; survey techniques involving e.g. questionnaires; experts interviews; brainstorming; Delphi methods; scenario methods; road-mapping; creativity methods; future workshops $[30,31]$.Scenario planning stimulates strategic thinking and helps to overcome thinking limitations by creating multiple futures [28]. These multiple futures do not predict the future, but explore multiple plausible future situations with the purpose of extending the sphere of thinking of the participants in the scenario development process $[28,33,34]$. A scenario is not a future reality but rather a means to represent it with the aim of clarifying present actions in light of possible and desirable futures [23]. Scenarios are not intended to represent a full description of the future, but rather to highlight central elements of a possible future and to draw attention to the key factors that will drive future developments [31]. Based on these futures present-day decisions can be guided and enabled $[28,35,36]$.

Because scenario planning developed as a practitioner-led domain in a great variety of settings, many different practices, methods, techniques and tools have been proposed and used [37]. Following Amer et al. (2013) three major schools or approaches for the development of scenarios can be distinguished: (1) intuitive logics, (2) probabilistic modified trends methodology and (3) the French approach of La prospective [28, 38]. In the latter the underlying principal of prospective thinking is that the future is not part of a predetermined temporal continuity [28], but it can be deliberately created and modelled [39, 40].

The term Foresight as used in this context emphasizes the explorative nature of the processes involved [30]. Futures can be classified as the probable, possible and preferable futures $[22,38,41]$, the foresight approach

\footnotetext{
1 An ERAnet is an instrument under the EU FP7 research programme providing a framework for actors implementing public research programmes to coordinate their activities e.g. by developing joint activities or by mutually supporting joint calls for trans-national proposals ([12]. COFASP: Cooperation in Fisheries, Aquaculture and Seafood Processing
} 
developing normative scenarios of the future and articulate idealistic future images so that scenarios can serve as a guiding vision to policy makers and provide a basis for future action [42].

Foresight and scenarios are not synonymous [23]; scenarios are constructed as an aid to decision-making. A major criterion for the success of a Foresight process is therefore the level of increase in awareness that the process creates amongst participants to equip them with an understanding of the plausible alternative futures, potential paths of action and consequences [30]. Kosow and Gaßner (2008) distinguish within the scenario process five ideal-typical phases of 1 ) identification of the scenario field, 2) identification of key factors, 3) analysis of key factors, 4) scenario generation, and, if necessary, 5) scenario transfer [31].

In section 2 the foresight method used is described. In section 3 the step by step results of the process are presented leading up to the construction of the scenarios that were used to develop the research needs forming the research agenda. In section 4 the topics for future research are described. Finally, section 5 contains a reflection on the findings and looks at the road ahead.

\section{Methodology}

The foresight study implemented within the COFASP ERAnet applied an analysis using scenarios, building a step by step examination of the most important factors influencing the future in fisheries, aquaculture and seafood processing. In this context the French approach of La prospective was applied due to the emphasis that is put on human decision-making, action consequences of future states, and the participation of the decision-maker in the whole foresight process [35].

In a world that is increasingly volatile, uncertain, complex and ambiguous in nature there are no onedimensional explanations, simplistic answers or quick fixes [29]. The process of the scenario based foresight was embedded and founded on two core pillars; the former pillar was the development of research based on a series of scenarios constructed during the project. The latter was the involvement of experts and stakeholders. Hence, the methodology followed here to construct the fisheries, aquaculture and seafood processing research agenda consisted of six logical steps [24-27], implemented during a series of five workshops, held between September 2013 and June 2014, which involved experts and stakeholders from the research community, the European fishing, aquaculture and seafood processing industry and their representative organisations, environmental NGOs and consumer organizations. The 92 participants, coming from across Europe, belonged to the fields of marine biology, marine ecology, fisheries and aquaculture economics, resource economics, marine governance, marine spatial planning, seafood processing, aquaculture and mariculture, maritime law, marine nature conservation, representatives of the fishing, mariculture and seafood processing industry and policy makers and resource managers. From the scientific community throughout the workshops we had a rather evenly distributed input from the fields of marine biology and ecology, aquaculture, fisheries technology, marine fisheries economics and resource economics and marine governance. Among the organisations that attended the workshops were members of COFASP, EFARO, JPI Oceans and SCARFish and representatives of organisations like AZTI Technalia; Baltic Sea Advisory Council; Defra (Department for Environment, Food and Rural Affairs), United Kingdom; CNR-ISMAR (National Research Council - Institute of Marine Sciences ); IEO (The Spanish Institute of Oceanography); IFREMER (L'Institut Français de Recherche pour l'Exploitation de la Mer); Matis, Iceland; Ministry of Rural Affairs, Estonia; MSS (Marine Scotland Science); Pelagic Advisory Council; The Research Council of Norway; Rannis, Iceland; STECF (Scientific, Technical and Economic Committee for Fisheries); Thuenen-Institute of Sea Fisheries; Thünen Institute of Fisheries Ecology; AquaTT; CEFAS (Centre for Environment, Fisheries \& Aquaculture Science, Lowestoft, United Kingdom); Client Earth; CNC (Euroshell); DTU Aqua; EAS (European Aquaculture Society); GFCM (General Fisheries Commission for the Mediterranean, Rome, Italy); MatureDevelopment; Ministry of Industries \& Innovation Iceland; North Atlantic Seafood Forum; Oceano XXI; SINTEF Fisheries and Aquaculture; Pelagic RAC; STECF (Scientific, Technical and Economic Committee for Fisheries); WWF (World Wildlife Fund, Utrecht, The Netherlands).

The constructed scenarios attempted to grasp a wide variety of possible futures, exploring multiple plausible future situations $[28,33,34]$. For each future scenario described, workshop participants were asked to identify most relevant research issues, fitting the flavour of the scenario in terms of issues to be addressed, the role of science in addressing these and the general socio-political considerations shaping this future world. The identified research issues under each foresight scenario were grouped and summarised into research topics. The most often identified and prioritised topics from the different scenarios were then combined into a single final list of topics to be addressed today in order to be ready for any future to come.

It should be noted that, in order to arrive at the topics for a research agenda, the aim of the process was to construct scenarios that would lay very much apart. By constructing different, perhaps even opposing, 'futures' it was easier to make a distinction between research issues that would only be relevant under certain (societal, environmental and economic) circumstances, and those research topics that would be relevant in all of the 
scenario's. In addition, the constructed scenarios cannot be classified as 'good' or 'bad', but are all possible to come about, based on the development of the specific drivers that have been identified. As mentioned above, these multiple futures do not predict the future, but explore multiple plausible future situations with the purpose of extending the sphere of thinking of the participants in the scenario development process.

Below, in a step wise fashion, the scenarios constructed will be described. In section 4, the combined list of priority research topics for the future is presented. The process resulted in a research agenda that is logically argued and based on an analysis made by stakeholders and experts which led to the identification of priorities having a scientific analytical basis as well as a societal reference [24-27].

\section{Building a research agenda}

In the first step of the Foresight process the system (and its sub-systems) under consideration was defined in terms of boundaries and time horizon. In the next step, for each system part, the key variables and their relationships were determined; the so called 'drivers ${ }^{2 \prime}$ of the system. After these drivers had been determined, each driver was documented in terms of defining a set of most relevant indicators for this driver and a description of how the driver developed over the past 20 years. Also for each driver a set of different hypotheses, or a number of "possible futures" was elaborated.

Based on the hypotheses for each individual driver hypotheses for the development of each subsystem were generated. These are what are called 'micro-scenarios'; possible developments for each of the subsystems. Connecting in a logical way the micro-scenarios of the different subsystems results in the so called "macroscenarios": possible futures for the entire system.

\subsection{The system}

The first stage concerns 'setting the scene'. Defining the purpose of the exercise, developing an understanding of the current situation, setting a time horizon, selecting the appropriate participants and defining the need for the scenario planning process are common aspects of the first stage [45]. The aim of the study was to develop a research agenda defining the research required in the medium term (15 years) to enable a sustainable exploitation and farming and retailing of aquatic resources and to be equipped to address by 2050 the main global challenge of accommodating the need for food for a world population of almost 10 billion people.

Considering all areas that would need to be covered, the world of fisheries, aquaculture and seafood processing was divided into 7 areas or subsystems:

A. Policy: political objectives and legislation in a EU and national and regional context. Including political and policy changes and interaction at different levels.

B. Economics/market: all aspects of the production distribution and consumption of goods and services. Demand versus supply.

C. Value chain: chain of activities to deliver a valuable product or service to the market.

D. Resource use: the use of marine resources and the competition between different users.

E. Society: Societal trends, demographics, and developments, including values around the marine system.

F. Natural system: biological, physical, chemical environment of human marine activities. The natural system including all animals, interactions, sediments.

G. Knowledge: information, understanding, facts, technology or skills acquired through research, or experience or education. Taking into account regional differences.

\subsection{Drivers}

The second stage covers identifying the key driving forces [45], identify the key factors that will have a strong influence over how the future will unfold [31]. While each driving force is seen to be impacting on the focal issue of concern and to have an influence on its future outturn, the nature of its outcome is likely to vary across different future scenarios. At this point, it is possible to consider the range of these outcomes, in terms of possibility and plausibility [21].

In Table 1 below for each of the identified sub-systems the relevant drivers are presented. For each driver the most important indicators were determined and a description of the development of the driver over the past 20

\footnotetext{
2 In a system there are many variables that can be described. Some of these variables will have a more than average impact on determining the future state of the (sub)system [25] . These are the so-called drivers. Drivers are defined as developments causing change, affecting or shaping the future $[43,44]$.
} 
years was elaborated. Subsequently for each driver a set of different hypotheses, or a number of "possible futures" were developed.

Table 1: Drivers by sub-system

\begin{tabular}{|c|c|c|c|c|c|c|}
\hline A. Policy & $\begin{array}{l}\text { B. Economics } \\
\text { /market }\end{array}$ & C. Value chain & $\begin{array}{l}\text { D. Resource } \\
\text { use }\end{array}$ & E. Society & $\begin{array}{l}\text { F. Natural } \\
\text { system }\end{array}$ & G. Knowledge \\
\hline $\begin{array}{l}\text { A1 Big issues: } \\
\text { food security, } \\
\text { energy, fresh } \\
\text { water } \\
\text { A2 Food safety } \\
\text { A3 Conservation } \\
\text { of resources } \\
\text { A4 Multi-level } \\
\text { governance } \\
\text { A5 } \\
\text { Regionalisation } \\
\text { A6 Stakeholder } \\
\text { influence } \\
\text { A7 Political } \\
\text { continuity } \\
\text { A8 Employment }\end{array}$ & $\begin{array}{l}\text { B1 Economic } \\
\text { climate } \\
\text { B2 Economic } \\
\text { signature } \\
\text { B3 Globalization } \\
\text { - competition } \\
\text { BRICS } \\
\text { B4 Trading } \\
\text { conditions and } \\
\text { opportunities } \\
\text { B5 Access to } \\
\text { capital (for } \\
\text { business) }\end{array}$ & $\begin{array}{l}\text { C1 Consumer } \\
\text { demand (user) } \\
\text { C2 Certification } \\
\text { standards and } \\
\text { traceability } \\
\text { C3 Valorisation of } \\
\text { raw material and } \\
\text { co-products } \\
\text { C4 Production } \\
\text { costs } \\
\text { C5 Product } \\
\text { development and } \\
\text { marketing }\end{array}$ & $\begin{array}{l}\text { D1 } \\
\text { Environmental } \\
\text { health status } \\
\text { D2 Access, user } \\
\text { rights and } \\
\text { alternatives } \\
\text { D3 Wants and } \\
\text { needs for } \\
\text { resources } \\
\text { D4 Technological } \\
\text { advancement }\end{array}$ & $\begin{array}{l}\text { E1 Demographics } \\
\text { E2 Population } \\
\text { wealth } \\
\text { E3 Media and } \\
\text { education } \\
\text { (marine literacy) } \\
\text { E4 Regional } \\
\text { differences }\end{array}$ & $\begin{array}{l}\text { F1 Physical and } \\
\text { chemical forcing } \\
\text { F2 Species } \\
\text { 'demographics' } \\
\text { F3 Resilience of } \\
\text { the ecosystem }\end{array}$ & $\begin{array}{l}\text { G1 Funding } \\
\text { G2 Motive for } \\
\text { generating } \\
\text { knowledge } \\
\text { G3 Reliability of } \\
\text { knowledge } \\
\text { G4 Access and } \\
\text { openness of } \\
\text { knowledge (IP) } \\
\text { G5 Uptake of } \\
\text { knowledge and } \\
\text { innovation } \\
\text { capacity }\end{array}$ \\
\hline
\end{tabular}

\subsection{Micro scenarios}

The third step encompasses selecting central themes and developing scenarios, using various techniques depending on the contextual setting of the exercise $[31,45]$. It is important to construct scenarios with an angle on consistency: in observing the different conceivable values of all key factors (drivers) decide which combinations behave consistently toward one another and may thus play a role in the construction of consistent scenarios [31].

In this step stories/narratives were constructed by choosing one hypothesis for each individual driver and matching them together with other hypotheses within a single sub-system. A story like this is called a microscenario: a possible development of that sub-system. The names of the micro scenarios are presented in Table 2 below.

Table 2: Overview of the names of the identified micro-scenarios per sub-system

\begin{tabular}{|c|c|c|c|c|c|}
\hline Sub-system & \multicolumn{5}{|c|}{ Micro-scenarios } \\
\hline A. Policy & $\begin{array}{l}\text { Don't worry be } \\
\text { happy }\end{array}$ & $\begin{array}{l}\text { Rabbit in the } \\
\text { headlights }\end{array}$ & $\begin{array}{c}\text { Command and } \\
\text { control }\end{array}$ & $\begin{array}{c}\text { Europe in splendid } \\
\text { isolation }\end{array}$ & \\
\hline $\begin{array}{l}\text { B. Economics } \\
\text { /market }\end{array}$ & $\begin{array}{c}\text { Too much monkey } \\
\text { business }\end{array}$ & $\begin{array}{c}\text { Money, money, } \\
\text { money }\end{array}$ & China Syndrome & Electric Stone Age & \\
\hline C. Value chain & $\begin{array}{c}\text { You can't always get } \\
\text { what you want }\end{array}$ & Corporate suit & Consumer's choice & Bric - a - Brac & \\
\hline D. Resource use & Too good to be true & We need to talk & Anarchy & $\begin{array}{l}\text { United we fail / OK } \\
\text { for some }\end{array}$ & $\begin{array}{l}\text { Brave new world; } \\
\text { after the war }\end{array}$ \\
\hline E. Society & Imagine & Gated communities & Push and Pull & & \\
\hline F. Natural system & $\begin{array}{c}\text { Life in a changing } \\
\text { world }\end{array}$ & $\begin{array}{c}\text { Changes towards the } \\
\text { collapse }\end{array}$ & $\begin{array}{c}\text { Strangers in the } \\
\text { night }\end{array}$ & Adam and Eve & \\
\hline G. Knowledge & Nirvana & $\begin{array}{c}\text { The Winner takes it } \\
\text { all }\end{array}$ & Copycat & $\begin{array}{c}\text { Knowledge a public } \\
\text { good }\end{array}$ & \\
\hline
\end{tabular}

\subsection{Macro scenarios}

The fourth phase involves condensing the list of central factors or bundling key factor values together in order to generate a relatively small number of meaningfully distinguishable scenarios [31]. This step includes the construction of a narrative for the scenario which allows for a check on plausibility and consistency and describe the vision which underlies the scenario in a social, economic, technical, political and cultural perspective (cf. Kosow and Gaßner, 2008).

Connecting the micro scenarios of the different sub-systems resulted in the so-called macro-scenarios: possible futures for the entire system. Four scenarios were developed, described below. For each of the scenarios a list of research priorities was developed. The question to address was: in this scenario, in this future world, what would be the needs of society and policy makers, what issues would they seek to address, and what would then be the focus of research to support this. Some of the individual research priorities are presented with each of the scenarios to provide an illustration of the direction research under the scenario would take. 


\section{The moral high ground}

This future scenario envisages a sophisticated, well-organized and well-controlled recreational and artisanal/ small-scale harvesting regime. Persuaded by the public, the EU takes the lead on taking a stand and developing a policy on how to harvest marine animals in a sustainable and low impact way. Besides that, consumers are very critical on ethical principles and public awareness about preserving the environment and carefully using the ecosystem services has led civil society groups, consisting of both environmental groups and small scale fisheries groups, to have a big influence on this. Together, they see the benefits of preserving the environment. Knowledge is a public good and there is public access to ecosystem information.

Under this scenario research issues focus on the development of high quality, low environmental impact niche products in which biotechnology searches for new materials, products from plants and substitutes for animal products. There will be fundamental research on the state and functioning of ecosystems. Low impact fishing methods, together with the improvement of efficiency in the small scale fleet will be developed. Research into organic aquaculture, primary producers, potentials for herbivore species, plant aquaculture, bivalves (shellfish), to lower costs relative to conventional methods will be undertaken, including research into aquatic animal health and welfare.

\section{"It's not EU, it's me..."}

The European project has failed. There is a permanent economic crisis with decreasing economic activities in Europe and a nationalistic political system with a shift to reactive "crisis management" with no cooperation among EU countries. As one consequence, Europe will face a shortage in food production and as a result of competing use of the marine environment and its resources, the marine ecosystem is in a poor environmental health status with reduced resilience and instable ecosystem communities. Demand for new knowledge and the ability to conduct research is low.

Under this scenario research issues focus on increasing food security and self-sufficiency for example through development of technology in the processing sector to changes in raw materials (e.g. other species, a wider range of sizes) and in aquaculture production. A framework for management of marine activities will be developed to ensure that resource use (including pollution) stays within identified boundaries. Identification of 'new' species, sources of feed, water treatment technology; increase water/feed efficiency will be set up, in combination with technical improvements to reduce waste and environmental impacts of activities. Increase efficiency of vessels and gears, of value chain, and of aquaculture production (e.g. feed conversion ratio, time to slaughter).

\section{EUtopia}

After the prolonged crisis of the first decennia of the second millennium the world economy, and of Europa, has veered back and is flourishing. EU policies and national policies fully align in the strive for enabling prosperity. Consumers drive developments in the fish produce and seafood market. The stable population with a richer middle class is focussing on health issues and the demand for seafood produce increases. There is an increase in the number of species in the ecosystem as a result of climate change but a decline in 'traditional species', yet, the net effect on ecosystem services and benefits are positive, resulting in even more productive ecosystems. People have a strong sense of self-responsibility, well-educated with knowledge and awareness of the sea. Fixing the main challenges for society is considered to be a public affair.

Under this scenario research issues focus on multi-annual planning of fisheries with contingency measures and an appropriate percentage of the stocks that can be removed by fisheries. The development of user-friendly stock reference models with an ecosystem approach with continued improvements in monitoring and data collection. Restoring certain species, using coordinated breeding programmes while considering species' adaptation to ecosystem change is considered. In processing, maximisation of filet yield and the use of all coproducts for high value products for feed, food, pharmaceuticals, cosmetics are of prime importance. Seaweed and seaweed processing will become important for production of all sorts of products from food and feed, proteins and bio-fuel to biodegradable bio-plastics.

\section{Fortress Europe... Not so splendid isolation}

Europe closes its borders and restricts free movement of capital, people and goods. With no common market, member states take back responsibilities for economic and other social strategies with maximal resource exploitation and use of marine space at the top of the agenda. Although ecosystem health is generally good, it becomes increasingly challenged due to increased human impact. Research is almost exclusively funded by private funds demanding for Intellectual Property rights. 
Under this scenario research issues focus on research programs based on a shared understanding of a need for long-term stock/resource protection and development of incentives to guarantee compliance of sustainable fishery objectives. Against a back drop of changing ecosystems and decreased supply of food from the sea, questions are raised on adaptation of the fishing industry (e.g. vessel types / equipment) and how by-catch and discards can be appropriately managed. In aquaculture the search is for species that could serve a high-value novel niche market. In a market characterised by multiple high-value (no bulk) products, what could be the role of small-scale and multi-purpose processing units?

\section{Topics for future research}

As mentioned above, the four scenarios developed sought to present possible futures, based on the conceivable development of individual drivers. As much as possible the scenarios sought to present different and perhaps opposing futures. For each of these futures the uncertainties, challenges and opportunities that research may answer were identified. The research issues identified for each scenario that were dealing within the same overarching research question were grouped into one research topic. Only topics that were identified as relevant in several of the scenarios were considered further. Based on this analysis, the list of areas and topics for further research, as presented below, was drafted. The underlying assumption was that if a research priority surfaces under a number of different scenarios, hence different futures, the likelihood that this research is needed in future is very likely. On the other hand, if specific research only is needed under a single specific scenario, the need to address this issue today is less likely. Below the overarching research themes from the different scenarios are presented.

In order to address the needs of the world population of 9.7 billion by 2050 it is logical to increasingly use the space, opportunities and resources our seas and oceans have to offer. Next to for example the production of fish and shellfish through capture fisheries and aquaculture increasingly the possibilities of enlarging the range of farmed species through the cultivation of algae, marine plants and other sessile marine organisms at lower trophic levels of marine chains will be exploited. Next to production of food from the sea the production of drinking water and renewable energy will increase. Yet, this should not come at the expense of increased pollution, noise or loss of biodiversity or populations of marine organisms, decreasing the overall resilience of the oceans. This raises the issue of optimising the use of marine space and dealing with conflicting interests. In order to do so, a number of challenges that are presented below will need to be addressed.

\section{Optimisation of Aquatic Food Production}

The production from fisheries, aquaculture and other marine production systems needs to be optimised: making the best use in terms of efficiency, effectiveness and coherence in using our marine space and resources. In the field of fisheries this will call for a focus on implementation of the Maximum Sustainable Yield principle and fisheries management plans for mixed fisheries. The latter needing to take into account the interaction of species in an ecosystem based context, including fishing of lower trophic levels. This calls for an implementation of the Ecosystem Approach and enhanced adaptive management systems which include the evaluation of impacts on the socio-ecological system.

For aquaculture this will call for the development of technology to make aquaculture more efficient in terms of production, health aspects of food, minimizing the risks of diseases, and reducing impact on the environment hence lowering the ecological footprint. Examples can be the development of multi-trophic aquaculture, recirculation technology and using the open sea for aquaculture production.

For marine production systems in general, management strategies need to be sensitive to variations in marine ecosystem resilience and abrupt ecological regime shifts. This centres for example on accounting for effects of climate and habitat change as well as marine pollution. For new production systems, such as increased seaweed and algae culture or exploitation of new (deep sea) resources, appropriate management practices, ownership and access rights and ownership over resources yet not explored need to be developed.

The latter brings with it the crucial issue of the distribution and management of Access and Ownership rights (and obligations). This includes concerns over spatial management and considerations of regionalisation and multipleuse of the sea in a single location.

Appreciating the marine environment and the value of food In order to strive for an optimal sustainable use of the seas it is important to be able to put a value to ecosystem goods and services. Related to this is the issue of costing the impact of activities on marine ecosystems and habitats and incorporating these costs into the production costs in the value chain. Together with non-economic values this analysis will provide a basis for societal cost-benefit analyses of different activities, especially in a world with increased competition for marine resources and space. A more realistic 
picture of all costs associated with marine activities will in turn provide important inputs into Marine Spatial Planning.

A major challenge is to change the general attitude towards the value of (sea)food, which includes the acceptance of all production costs being assimilated in the final consumer price, including the environmental footprint and so called externalities ${ }^{3}$. Production costs should truly reflect economic, environmental and societal costs.

\section{Optimise Marine Spatial Planning}

Crucial to arrive at marine sustainability is planning the optimal use of marine space and resources. Therefore there is a need for optimising and harmonising Marine Spatial Planning processes, also at the regional level. Smart spatial planning concepts will enable combining multiple-use objectives with effective resource and nature conservation needs. Noting the scarcity of valuable ocean space, especially competition over the near shore area, the concept of multiple-use in a single location needs to be further explored. Examples can be multi-purposing windfarms for seaweed production, aquaculture and tidal energy.

\section{Product Oriented Management}

To support food security and safety and competiveness of the European seafood sector fisheries, aquaculture and marine production in general should be integrated into a holistic seafood production system based on reversing the perspective from resource-based to product-based management. In line with the EU FOOD 2030 initiative, seeking to transform and future-proof our food systems to be sustainable, resilient, competitive, diverse, responsible and performant in their provision of accessible, healthy and sustainable food and diets for all, there is a need in Marine management to turn the focus to questions like the kind of products desired and how should they be produced best, to ensure sustainability of entire food production chains from catch/production to plate/consumption. This food (security) product-based management should be further developed.

\section{Less complex management system}

An increasing number of marine activities with multiple objectives leads to a growing complexity of the management of our seas and oceans. There is a tendency to increase the number of rules, policies and regulations to govern the use of the seas. A major challenge is to avoid overregulation and reduce complexity to keep the management system transparent and efficient. The aim should be for a level playing field with high standards instead of a race to the bottom towards minimal standards. Strive should also be to arrive at defining and maintaining global standards and laws. Hence, despite quite a lot of demands on the future management systems to more comprehensively supervise and regulate the use of our seas and oceans, there is a simultaneous call to seek to reduce the complexity of the management system, e.g. via switching towards results based management.

Blue growth in the light of climate change and pollution

Competitiveness of the European seafood sector relies on production and management systems that are flexible enough to react to a frequently and rapidly changing world. Climate change, rapid technological development and a policy landscape characterised by severe alterations and a high degree of uncertainty are the main drivers for these changes. From the perspective of the Blue Economy there is a clear need for a clean and healthy environment to produce in, be it for capture fisheries, aquaculture or other forms of marine production. A healthy and robust ecosystem is to ensure the productivity of the production systems, the resilience of the natural systems and safeguarding food safety. The latter for example calls for the immediate addressing of the plastic pollution of the seas.

Circular-, no-waste economy (including plastic waste in the ocean).

The circular economy concept, or cradle to cradle production, focuses on optimising the use of resources by the industry, but also making best use of available technology and infrastructures, such as co-use of vessels and production platforms by different users (including research). An especially important aspect is addressing the question of how to change the general perception towards an attitude of "no waste".

Optimising towards no waste requires including all costs of production for every resource harvested, including costs of processing and marketing throughout the entire production chain. This can be achieved by making better use of the harvested produce and develop the necessary new technology to do so and coordinate marine resource harvesting, production and use with other food production systems. The main driver behind these activities should be "no more waste". Although an impact on the environment cannot be completely ruled out,

\footnotetext{
3 Externalities are costs (or benefits) that are a consequence of an economic activity experienced by unrelated third parties; it can be either positive or negative. Pollution emitted by a factory that spoils the surrounding environment and affects the health of nearby residents is an example of a negative externality. (cf. [46] A.A. Papandreou, Externality and institutions, Oxford University Press1998, [47] R. Cornes, T. Sandler, The theory of externalities, public goods, and club goods, Cambridge University Press1996, [48] S.A. Lin, Theory and measurement of economic externalities, Academic Press2014.).
} 
the footprint of production should be minimised, for example in aquaculture by managing feed ingredients, growth, escapes, diseases/parasites, and chemical discharges.

The circular economy ${ }^{4}$ has to be developed with an appropriate level of regulation and checks and balances on resource use, access and ownership to avoid imbalanced and unfair exploitation. It should be organised in such a way that openness, initiation of new markets, internalizing external costs and avoiding monopolies are assured. Quite a lot of the technology to achieve this is already available; the main challenge lies in the restructuring of the current linear economy (a 'take, make, dispose' model of production [52]).

Eco-engineering: from manipulation to informed constructing

Gene-engineering and eco-engineering are two concepts that can help to optimise production and integrated use of marine space. Eco-engineering is already widely used around the world. Despite this wide spread use the possible significant effects on ecosystem structure and functioning and health have not yet been fully explored. Further knowledge is still required to predict possible effects at a wider ecosystem level. Also, the management of these systems needs to be developed and put in place to avoid/minimize negative impacts due to unsustainable use.

The lack of understanding of (the effects of) gene-engineering evokes a rather negative attitude towards these techniques by the general public. In this field the marine sciences are lacking behind developments in terrestrial sciences.

In order to facilitate a more rational discussion and decision making in the marine realm it is necessary to better understand the ecosystem effects of gene- and ecosystem-engineering and to plan sustainable management. General acceptance of concepts such as Building with Nature and using eco-engineering to enhance productivity will then be enhanced.

Make more efficient use of already collected data for rational decision making.

A major challenge is to get the increasing stream of collected data publicly available and turned into information (products) in such a way that it will assist to inform decision making at all levels including all relevant stakeholders. This includes integrated global monitoring - for example physical, biological as well as monitoring of fishing activities - and the challenges to standardize methodologies and techniques as well as the provision of real time information for real-time management and decision support at the integrated socio-ecological level. In addition, techniques to manage the increasing stream of (big) data, analyse and transform data into usable information have to be developed and standardized. In this view, further implementation and use of already existing instruments such as the European Marine Observation and Data network (EMODnet) would be advisable. New technologies for data collection (less invasive, highly automated and efficient) across all fishing activities have to be developed further.

At the level of policy development and (resource) management the governance set up has to be designed as to reflect the necessity to operate at the appropriate geographical and political (ecosystem) level. This also needs to reflect the inclusion of a growing assembly of relevant stakeholder groups in decision-making and the call to include citizens' science into the system.

\section{In Conclusion}

In order to address the needs of the world population of 9.7 billion by 2050 it is logical to increasingly use the space, opportunities and resources our seas and oceans have to offer. The foresight approach applied resulted in normative scenarios of the future and a topical list of areas which science and policy makers should address urgently to future proof the system of today to be ready for the challenges of 2050.

This foresight started with these global challenges and sought to address them in a research agenda from the perspective of the European context. Although in the scenario's the relationship between the EU and the rest of the world was explicitly considered, in the final list of research topics this relationship does not explicitly surface. Although the results have a wider global application, as the issues it seeks to address are of a global nature, in future it should be considered to address the fisheries, aquaculture and seafood processing challenges in a clear global perspective.

At the European level there is already increasingly attention for the development of the Blue Economy and for an increase in the production of food and other bio-products from our oceans in a sustainable and competitive

\footnotetext{
4 A circular economy is an industrial economy that promotes greater resource productivity aiming to reduce waste and avoid pollution by design or intention, and in which material flows are of two types: biological nutrients, designed to re-enter the biosphere safely, and technical nutrients, which are designed to circulate at high quality in the production system without entering the biosphere as well as being restorative and regenerative by design $[49-51]$.
} 
way. However, in order to truly bring about this required Blue Revolution [53] it appears logical to render substantial effort to the science and innovation needed to support this development. This will imply developing scientific support to policy development and support to innovation in the marine industry [54]. But equally important is providing the science to society to induce a behavioural change towards on the one hand a sustainable, no-waste Blue economy with consumers valuing the use of our seas. And, on the other hand acknowledging the fact that our seas and oceans provide a huge potential to address the challenges of the future.

\section{Acknowledgements}

The authors would like to thank all of the participants that were taking part in the process of scenario building and constructing the research agenda. This document does not reflect the individual opinions of these participants, nor does this document necessarily reflect the view of the European Commission nor anticipates the Commission's future policy. The work for this research was implemented under the COFASP ERANet which received funding from the European Union's Seventh Framework Programme for research, technological development and demonstration under grant agreement no 321553. The analysis of the results was funded by EFARO and implemented by Wageningen Marine Research under agreement no 4311100037.

We are grateful to the two reviewers who helped us in improving the manuscript.

\section{References}

[1] C. Béné, R. Arthur, H. Norbury, E.H. Allison, M. Beveridge, S. Bush, L. Campling, W. Leschen, D. Little, D. Squires, Contribution of fisheries and aquaculture to food security and poverty reduction: Assessing the current evidence, World Development 79 (2016). 177-196.

[2] SAPEA, Food from the Oceans. How can more food and biomass be obtained from the oceans in a way that does not deprive future generations of their benefits? SAPEA Evidence Review Report. Accompanies the Scientific Opinion of the High-Level Group of Scientific Advisors, 2017.

[3] European Commission Scientific Advice Mechanism, Scoping paper: Food from the oceans, Brussels, 2016.

[4] J.G. Conijn, P.S. Bindraban, J.J. Schröder, R.E.E. Jongschaap, Can our global food system meet food demand within planetary boundaries?, Agriculture, Ecosystems \& Environment 251(Supplement C) (2018) 244256.

[5] Commission of the European Communities, Communication from the Commission to the European Parliament, the Council, the European Economic And Social Committee and the Committee of the Regions. Blue Growth opportunities for marine and maritime sustainable growth. COM(2012) 494 final, Brussels, 2012.

[6] European Commission Scientific Advice Mechanism, Expert workshop on Food from the Ocean - paving the way to a Scientific Opinion by the High Level Group of Scientific Advisors, 2017.

https://ec.europa.eu/research/sam/index.cfm?pg=oceanfood. (Accessed 28-11-2017 2017).

[7] J. Bell, L. Paula, T. Dodd, S. Németh, C. Nanou, V. Mega, P. Campos, EU ambition to build the world's leading bioeconomy-Uncertain times demand innovative and sustainable solutions, New biotechnology (2017). [8] Commission of the European Communities, Innovation in the Blue Economy: realising the potential of our seas and oceans for jobs and growth. $\operatorname{COM(2014)~} 254$ final/2, Commission of the European Communities, Brussels, 2014.

[9] European Commission, FOOD 2030 High-level Conference background document, 2016.

[10] European Commission, International ocean governance: an agenda for the future of our oceans JOIN(2016) 49 final, Brussels, 2016.

[11] European Commission, Food from oceans, 2017.

https://ec.europa.eu/research/sam/index.cfm?pg=oceanfood. (Accessed 28-11-2017 2017).

[12] European Commission, ERA-NET scheme under FP7, 2013. http://ec.europa.eu/research/era/era-netfp7 en.html. (Accessed 28-11-2017 2017).

[13] European Commission, Sustainable Agriculture, Forestry and Fisheries in the Bioeconomy: A Challenge for Europe 4th SCAR Foresight Exercise, 2015.

[14] SCARFish, Overview on fisheries and aquaculture research priorities and coverage of these by projects 2017.

[15] JPI Oceans Strategic Research and Innovation Agenda 2015-2020 Programming Initiative Healthy and Productive Seas and Oceans, Brussels, 2015.

[16] Bluemed, Research and innovation initiative for blue jobs and growth in the Mediterranean area. Strategic research and innovation agenda, Brussels, 2015.

[17] BONUS, Strategic research agenda 2011-2017, update 2014 . The joint Baltic Sea research and development programme, 2014.

[18] European Marine Board, Navigating the Future - III 2006.

[19] European Marine Board, Navigating the Future - IV, (2013).

[20] Marine Biotechnology ERA-NET, EMB Policy brief. Marine Biotechnology. Advancing Innovation in Europe's Bioeconomy, 2017.

[21] G. Cairns, G. Wright, Building on the Basic Method: Power, Ethics and Critical Scenario Method, Scenario Thinking: Preparing Your Organization for the Future in an Unpredictable World, Springer International Publishing, Cham, 2018, pp. 85-103. 
[22] O. Saritas, S. Burmaoglu, The evolution of the use of Foresight methods: a scientometric analysis of global FTA research output, Scientometrics 105(1) (2015) 497-508.

[23] P. Durance, M. Godet, Scenario building: Uses and abuses, Technological Forecasting and Social Change 77(9) (2010) 1488-1492.

[24] L. van Hoof, A. Payne, M. Evrard, V. Lamblin, G. Tserpes, C. Cahu, L. Antoine, A. Iversen, J. Pinnegar, The future of fisheries and aquaculture: trends and developments, in: L.v. Hoof, A. Payne (Eds.) FEUFAR project report, EFARO, IJmuiden, 2008, pp 26-118

[25] L. van Hoof, FEUFAR: the Futur-e of European Fisheries and Aquaculture Research, European Parliament, Brussels, 2008

[26] L. Van Hoof, J. Steenbergen, A Methodology for a Scenario Analysis, in: COFASP ERAnet (Ed.) 2013, pp 47-53.

[27] COFASP, Summary results of Foresight study in COFASP, 2014.

[28] M. Amer, T.U. Daim, A. Jetter, A review of scenario planning, Futures 46(Supplement C) (2013) 23-40.

[29] M.J. Burrows, O. Gnad, Between 'muddling through' and 'grand design': Regaining political initiative - The role of strategic foresight, Futures (2017), 6-17.

[30] J. Schatzmann, R. Schäfer, F. Eichelbaum, Foresight 2.0 - definition, overview \& evaluation. , European Journal of Futures Research 1(1) (2013) 1-15.

[31] H. Kosow, R. Gaßner, Methods of future and scenario analysis: Overview, assessment, and selection criteria, Bonn, 2008.

[32] G. Ringland, The role of scenarios in strategic foresight, Technological Forecasting and Social Change 77(9) (2010) 1493-1498.

[33] S.P. Schnaars, How to develop and use scenarios, Long range planning 20(1) (1987) 105-114.

[34] M. Godet, The art of scenarios and strategic planning: tools and pitfalls, Technological forecasting and social change 65(1) (2000) 3-22.

[35] J. Iden, L.B. Methlie, G.E. Christensen, The nature of strategic foresight research: A systematic literature review, Technological Forecasting and Social Change 116(Supplement C) (2017) 87-97.

[36] J.A. Dator, Advancing futures: Futures studies in higher education, Greenwood Publishing Group2002.

[37] M.J. Spaniol, N.J. Rowland, The scenario planning paradox, Futures (2017).

[38] P. Bishop, A. Hines, T. Collins, The current state of scenario development: an overview of techniques, Foresight 9(1) (2007) 5-25.

[39] H. De Jouvenel, Prospective for a new citizenship, Futures 18(2) (1986) 125-133.

[40] H. De Jouvenel, A Brief Methodological Guide to Scenario Building, Technological Forecasting and Social Change 65(1) (2000) 37-48.

[41] L. Börjeson, M. Höjer, K.-H. Dreborg, T. Ekvall, G. Finnveden, Scenario types and techniques: towards a user's guide, Futures 38(7) (2006) 723-739.

[42] F.A. Van Vught, Pitfalls of forecasting: fundamental problems for the methodology of forecasting from the philosophy of science, Futures 19(2) (1987) 184-196.

[43] European Foresight Platform, Megatrend / Trend / Driver / Issue, 2010. http://www.foresight-

platform.eu/community/forlearn/how-to-do-foresight/methods/analysis/megatrend-trend-driver-issue/. (Accessed 28-11-2017 2017).

[44] FAO Forward Thinking Platform, A Glossary of Terms commonly used in Futures Studies, (2014).

[45] M. Hussain, E. Tapinos, L. Knight, Scenario-driven roadmapping for technology foresight, Technological Forecasting and Social Change 124(Supplement C) (2017) 160-177.

[46] A.A. Papandreou, Externality and institutions, Oxford University Press1998.

[47] R. Cornes, T. Sandler, The theory of externalities, public goods, and club goods, Cambridge University Press1996.

[48] S.A. Lin, Theory and measurement of economic externalities, Academic Press2014.

[49] P. Lacy, J. Rutqvist, Waste to wealth: The circular economy advantage, Springer2016.

[50] D. Gallaud, B. Laperche, Circular Economy, Industrial Ecology and Short Supply Chain: Towards

Sustainable Territories, John Wiley \& Sons 2016.

[51] M. Lieder, A. Rashid, Towards circular economy implementation: a comprehensive review in context of manufacturing industry, Journal of Cleaner Production 115 (2016) 36-51.

[52] Ellen MacArthur Foundation, What is a circular economy?, 2017.

https://www.ellenmacarthurfoundation.org/circular-economy (Accessed 29-11-2017 2017).

[53] Wageningen University \& Research, It's about time for a blue revolution. Food from water to feed the world, 2016. https://www.wur.nl/en/Expertise-Services/Research-Institutes/marine-research/Dossiers/Itsabout-time-for-a-blue-revolution.htm. (Accessed 29-11-2017 2017).

[54] COFASP, Strategic Research agenda for Fisheries, Aquaculture and Seafood Processing, 2015. 